\title{
International Transfers and Dutch Disease: Evidence from South Asian Countries
}

\author{
Md. Bakhtiar Uddin ${ }^{\dagger}$ \\ Syed Mansoob Murshed ${ }^{ \pm}$
}

\begin{abstract}
We investigate the Dutch Disease impact of migrant's remittances and foreign aid using a yearly panel data of eight South Asian countries for the period of 1975-2013. An increase in per capita remittances erodes international competitiveness by appreciating the real effective exchange rate, also leading to a fall in traded to non-traded goods production ratio in the economy; hardly any statistically significant impact of foreign aid on these variables is detected. These point to premature deindustrialization consequences of large remittance inflows that could slow down structural transformation towards manufacturing. Although remittances and foreign aid may have a significant impact on poverty alleviation in this region, policy planners should pay attention to more effective utilization of remittances and foreign aid.
\end{abstract}

\section{Keywords}

Dutch Disease, Foreign aid, Real Effective Exchange Rate, Remittances, Premature deindustrialization.

\section{Introduction}

International transfers of remittances and foreign aid play an important role in the total financial inflows into developing countries across the world. Although remittances have a positive impact on various socio-economic development indicators at both micro and macro level, it also has adverse effects, such as the 'Dutch Disease'. South Asian countries are among the prominent recipients of both remittances. The aim of this paper is to examine the Dutch Disease impact of international transfers in terms of migrant's remittances and foreign aid, using panel data of eight countries in South Asia for the period of 1975 to 2013 controlling for country heterogeneity and time fixed effects.

† Jatiya Kabi Kazi Nazrul Islam University, Trishal, Mymensingh, Bangladesh, bakhtiareco@yahoo.com. I am grateful to the Netherlands Fellowship Programme (NFP) for financing my study at the ISS.

\pm International Institute of Social Studies (ISS), Erasmus University Rotterdam, The Hague, The Netherlands and Coventry University, UK, murshed@iss.nl. (Corresponding Author). We are grateful to an anonymous referee of this journal for valuable comments that have improved the paper. 
International transfers have both positive and negative effects on an economy. On the positive side are a wide range of effects such as increase in international reserves, accumulation of human and physical capital, financial development and poverty reduction (see Adams and Page 2005, Barajas et al. 2009, Giuliano and Ruiz-Arranz 2005). Remittances improve macroeconomic stability and reduce output volatility as well (Chami, Hakura and Montiel 2009). At the micro level, remittances increase household welfare through consumption smoothening, and have an important part to play in poverty reduction by raising the consumption of poor and near-poor households. Remittances also work as insurance for migrant sending households against dips in income due to natural calamities, crop failure or economic downturns (Yang 2008, Yang and Choi 2007). Households those receive remittances may experience a fall in fertility (Naufal and Vargas-Silva 2009). Similarly, foreign aid may also bear multifaceted benefits in the way of easing balance of payments constraints, financing capital goods imports, alleviating poverty; investing in health, education and infrastructure; thereby stimulating growth (see Burnside and Dollar 2000, Fischer 2009, Sachs 2009).

On the flip side, a large inflow of international transfers such as remittances and foreign aid can cause real exchange appreciation, resulting in diminished external competitiveness, eventually impacting negatively on the traded (manufacturing) sector. This phenomenon has been labeled the "Dutch Disease", first coined in 1977 by The Economist magazine to refer the unfavorable effects of gas revenues, following the discovery of natural gas, on the manufacturing sector in the Netherlands‡.

Globally, in 2014, remittances flows to developing countries increased to $\$ 436$ billion, which was a 4.4 percent higher than in 2013 (World Bank, 2015).

Figure 1: External inflows to developing countries

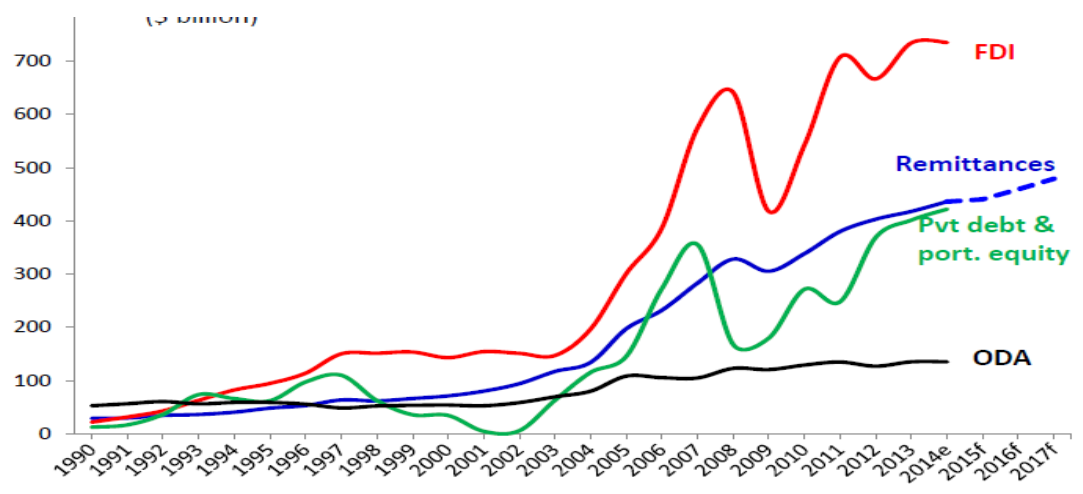

Source: Migration and Development Brief 24. World Bank. 2015

$\ddagger$ The Dutch Disease"(November 26, 1977). The Economist, pp.82-83 (as cited in NsorAmbala 2015) 
Remittances flows to developing countries have become stable, outpacing Official Development Assistance (ODA) and private capital flows (Figure 1).

Mundell (1957) theoretically demonstrated that factor mobility is a substitute for international trade in bringing about factor price equalization, and by implication convergence of wages and prices. In line with this, certain South Asian countries seem to export unskilled or semi-skilled manpower abroad, especially to the GCC $s$ countries, earning substantial remittances. According to World Bank (2015) statistics, remittances to South Asian countries increased by 4.5 percent in 2014 compared to a 2.5 increase in 2013. In this region, Pakistan saw a sharp rise in remittances (16.6 percent increase), while Bangladesh and Sri Lanka experienced 9.6 and 8 percent increases, respectively in 2014. However, India and Nepal, experienced a fall in remittances. South Asian countries like Bangladesh, India, and Pakistan are in the top ten remittance recipient countries in the world. In terms of remittances receipt, in 2014; India, Bangladesh and Pakistan were ranked $1^{\text {st }}, 7^{\text {th }}$ and $8^{\text {th }}$, respectively (Figure 1.2). Remittances account for a substantial proportion of GDP in South Asian countries as well.

Figure 2: Top ten remittance recipient in 2014

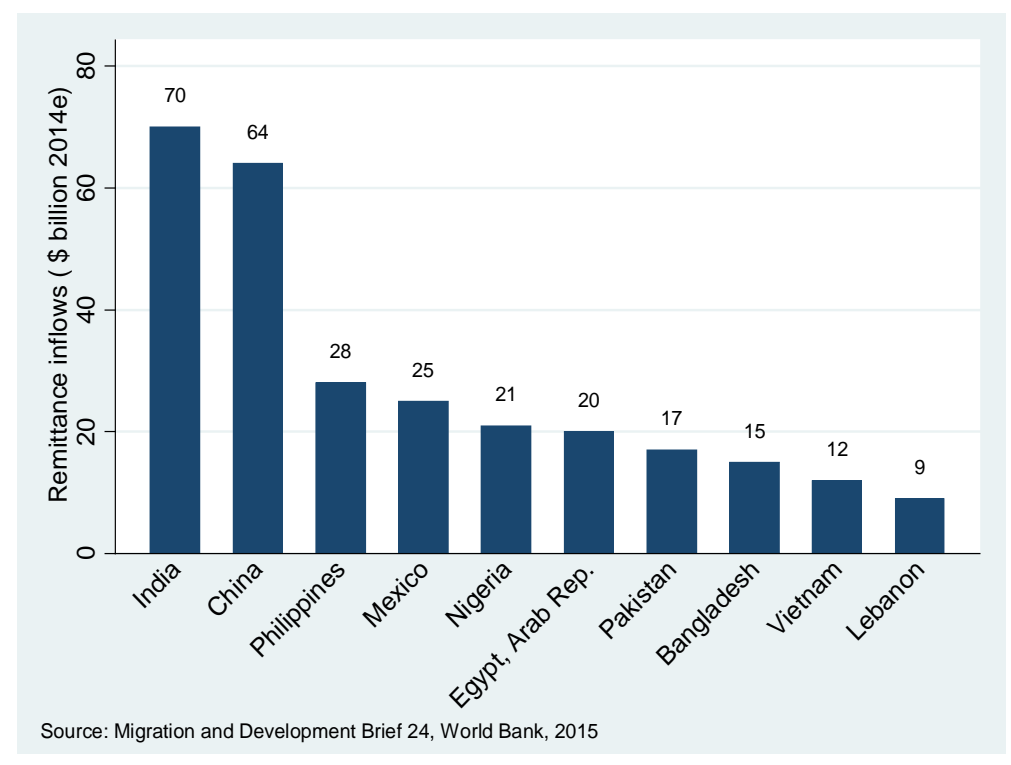

For example, remittances inflows to Nepal accounted for 29 percent of GDP in 2013. Remittances also accounted for 6 to 10 percent of GDP in Sri Lanka, Bangladesh, Pakistan and India (Figure 3). Moreover, remittances have become one of the main sources of international reserves in this region. In Pakistan, remittances were 191 percent of international reserves in 2013, which was the highest percentage among all other South Asian countries. While remittances

$\$$ Bahrain, Kuwait, Oman, Qatar, Saudi Arabia, and the United Arab Emirates. 
were 86, 83, 77 and 23 percent of international reserves in Sri Lanka, Nepal, Bangladesh, and India, respectively (Figure 3).

\section{Figure 3: Remittances as percent of GDP and international reserves} in South Asia (2013)

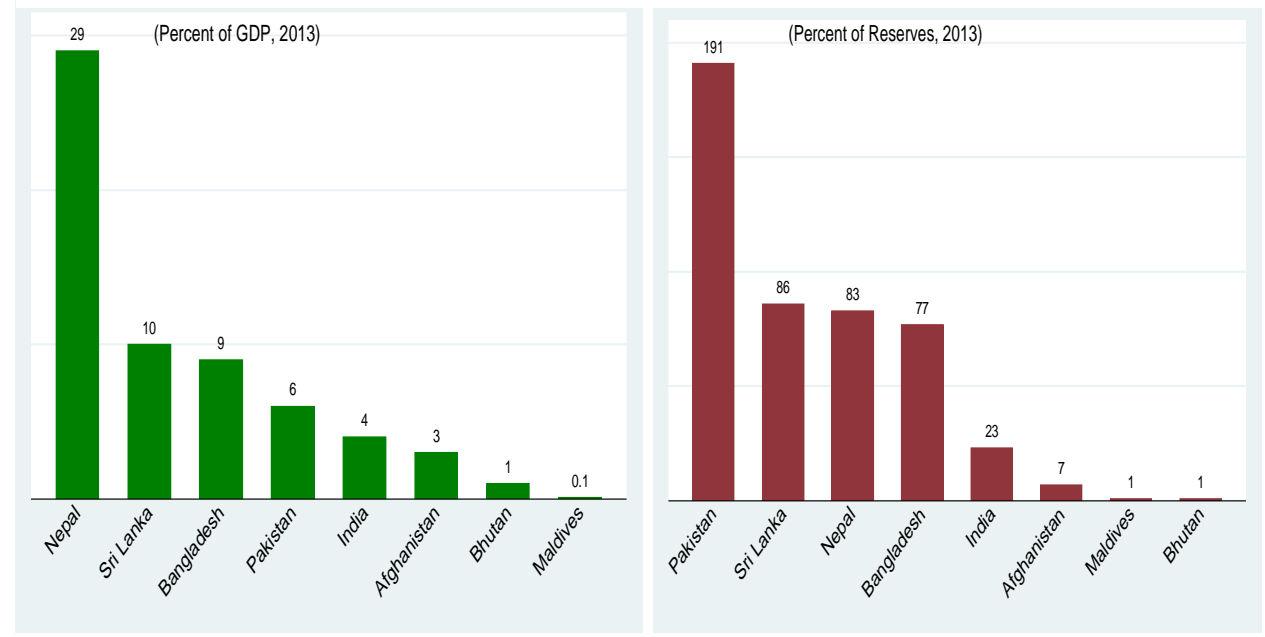

Source: Migration and Development Brief 24, World Bank, 2015

Figure 4 shows remittances as percent of total exports of goods and services in South Asian countries in 2014. In Nepal, remittances were about two and half times of exports. In Bangladesh, Pakistan and Sri Lanka remittances were 42 to 56 percent of exports. In India, however, this figure was much lower (14 percent) compared to other South Asian countries.

Migrant's remittances to this region have been growing at a high rate. Table 1 presents migrant's remittances figures for three decades. During 1980s on average remittances as percent of GDP were 2.7 in Bangladesh, whereas the figure increased to average 9.9 during 2010 s.

\section{Figure 4: Remittances as percent of total exports (2014e)}

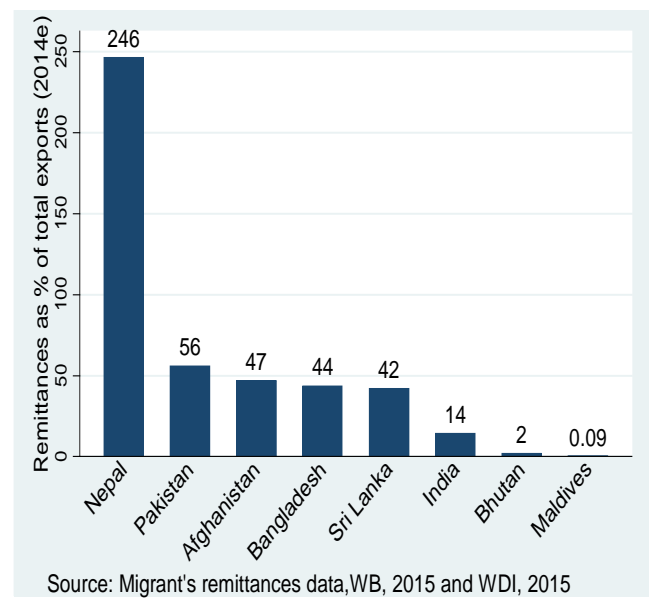

Within three decades this figure goes up by more than three and half times. It also increased by more than three times in India within this time period. Remittances data during 1980s for Nepal are not available. During 2000s on average remittances were 13.2 percent of GDP of Nepal and within a decade this figure jumps to average 25.4 percent of GDP. Remittances figures also show similar upward trends in Sri Lanka. The only exception is Pakistan. During 1980s on average remittances were 7.4 percent of GDP, while this figure de- 
creased to average 5.9 percent of GDP during the first four years of 2010s. Per capita remittances increased more than the share of remittances in GDP. Remittances to other three South Asian countries, Afghanistan, Bhutan and Maldives, are not substantial.

Table 1: Decade average of remittances and foreign aid

\begin{tabular}{|c|c|c|c|c|c|c|c|c|c|c|c|c|}
\hline \multirow[b]{2}{*}{ Country } & \multicolumn{4}{|c|}{$1980 \mathrm{~s}$} & \multicolumn{4}{|c|}{$2000 \mathrm{~s}$} & \multicolumn{4}{|c|}{$2010 s^{* * *}$} \\
\hline & $\begin{array}{l}\text { Remit- } \\
\text { tance ( } \\
\% \text { of } \\
\text { GDP) }\end{array}$ & $\begin{array}{l}\text { Remit- } \\
\text { tance } \\
\text { (per } \\
\text { capita)** }\end{array}$ & $\begin{array}{l}\text { Aid } \\
(\% \text { of } \\
\text { GDP })\end{array}$ & $\begin{array}{l}\text { Aid*( Per } \\
\text { capita) }\end{array}$ & $\begin{array}{l}\text { Remit- } \\
\text { tance( } \\
\% \text { of } \\
\text { GDP) }\end{array}$ & $\begin{array}{l}\text { Remit- } \\
\text { tance } \\
\text { (per } \\
\text { capita) }\end{array}$ & $\begin{array}{l}\text { Aid } \\
(\% \text { of } \\
\text { GDP })\end{array}$ & $\begin{array}{l}\text { Aid( Per } \\
\text { capita) }\end{array}$ & $\begin{array}{l}\text { Remit- } \\
\operatorname{tance}(\% \\
\text { of GDP) }\end{array}$ & $\begin{array}{l}\text { Remit- } \\
\text { tance } \\
\text { (per } \\
\text { capita) }\end{array}$ & $\begin{array}{l}\text { Aid } \\
(\% \text { of } \\
\text { GDP })\end{array}$ & $\begin{array}{l}\text { Aid }( \\
\text { Per } \\
\text { capita) }\end{array}$ \\
\hline Afghanistan & - & - & 0.8 & 3.219 & 1.122 & 4.678 & 40.3 & 107.348 & 1.996 & 12.999 & 37.2 & 229.442 \\
\hline Bangladesh & 2.699 & 6.082 & 6.467 & 14.621 & 7.241 & 35.742 & 2.105 & 9.344 & 9.944 & 84.434 & 1.445 & 12.517 \\
\hline Bhutan & - & - & 11.6 & 50.112 & 0.290 & 4.929 & 10.9 & 129.583 & 0.689 & 16.499 & 8.3 & 198.469 \\
\hline India & 1.067 & 3.247 & 0.784 & 2.376 & 3.092 & 23.652 & 0.204 & 1.393 & 3.471 & 51.608 & 0.139 & 2.066 \\
\hline Maldives & 1.549 & 8.611 & 17.2 & 82.086 & 0.282 & 11.529 & 3.2 & 121.122 & 0.145 & 9.402 & 3.3 & 215.457 \\
\hline Nepal & - & - & 9.670 & 16.612 & 13.182 & 49.094 & 6.145 & 20.269 & 25.367 & 176.941 & 4.404 & 30.638 \\
\hline Pakistan & 7.395 & 25.129 & 2.840 & 9.802 & 3.808 & 28.187 & 1.642 & 11.167 & 5.937 & 71.158 & 1.295 & 15.129 \\
\hline Sri Lanka & 5.117 & 18.601 & 8.480 & 30.572 & 7.625 & 99.268 & 2.477 & 31.166 & 9.172 & 263.826 & 0.912 & 25.458 \\
\hline
\end{tabular}

Notes: *Aid consists of Net Official Development Assistance (ODA) plus official foreign aid. ** Both remittances per capita and aid per capita are in US \$. *** Up to 2013.

Source: Authors' calculation based on World Development Indicators (WDI) 2014, World Bank.

Foreign aid flows, however, to South Asia are not as significant as remittances. Only Afghanistan receives a substantial amount of foreign aid. In the 2000 s and 2010s, on average, foreign aid to Afghanistan were 40.3 and 37.2 per cent of GDP, respectively. Bhutan also received aid amounting to about 10 percent of its GDP during the study period. Table 1 reveals that the GDP share of foreign aid was higher than remittances in the 1980s, and then foreign aid's importance gradually diminished. Each year a great number of people from South Asian countries migrate abroad for better employment opportunities. In Bangladesh from 1976 to 2015, a total of about 9.5 million (about 5.93 percent of total population) workers have migrated to all over the world for employment*. There are five million Indian workers across the globett. The Indian diaspora constitutes 25 million people in some 110 countries, which is the second largest diaspora in the world (Afram, 2012). In Nepal, a total of about 2 million people (about $7.3 \%$ of total population) were reported missing in 2011

** Bureau of Manpower, Employment and Training (BMET), Ministry of Expatriates' Welfare and Overseas Employment, Bangladesh.

\# Annual Report, 2014-15, Ministry of Overseas Indian Affairs, India 
census. They are believed to be working abroad\#. Up to December 2013, a total of 7.8 million Pakistanis (about $4.17 \%$ of the population) were living/working/studying all over the worldss. An estimated 1.7 million (almost $25 \%$ of total population) Sri Lankans were employed abroad in $2013^{* * *}$. As a whole, a total of 70 million people of South Asian origin live around the world (Burki 2013, as cited in Rahman 2014:3). In addition to this, each year a good number of workers migrate to other countries through illegal channels.

This study emphasizes the premature deindustrialization perspective in South Asian countries as a consequence of Dutch Disease effects of migrant remittances and foreign aid. Earlier studies put little or no emphasis on the resource movement effect. Thus, this paper will contribute to the literature of the Dutch Disease effects in South Asian countries resulting from international transfers. Section 2 outlines the theoretical approach and existing empirical literature, section 3 presents the methodology and data, section 4 contains our results, followed by conclusions in section 5 .

\section{Theoretical Approach and Empirical Evi- dence}

The issue of international transfers was debated between John Maynard Keynes and Bertil Ohlin in 1929 in connection with German reparation payments following the First World War. According to Keynes, the reparation payments were a burden to Germany; the transfer would require price and cost reductions in the export sector, which in turn would cause a deterioration in terms of trade. Ohlin, however, argued that because of income effects on the recipients of transfers, the terms of trade in the donor country would be unchanged (Brakman and Marrewijk 1998: 22). Leontief (1936) argued that the donor would gain from an international transfer. Samuelson (1947), however, pointed out that in a two-good, two-country, distortion-free Walrasian competitive equilibrium, the welfare of the recipient would increase at the expense of the donor.

Salter (1959) and Swan's (1960) seminal work showed a rise in domestic spending due to the transfer, and an appreciation of the real exchange rate due to the balance of payments surplus in a small open economy. Also, because of the spending effect, the demand for non-tradables increases along

\# Labour Migration for Employment: A Status Report for Nepal, 2013/14, Ministry of Labour and Employment, Nepal.

\$S Final year book 2013-14, Ministry of Overseas Pakistanis and Human Resource Development, Pakistan.

${ }^{* * *}$ Ministry of Foreign Employment, Sri Lanka. 
with its relative price. Consequently, there is a resource re-allocation with productive resources moving to the non-traded sector from the traded sector. This is the essence of what was later termed the Dutch Disease. Corden and Neary (1982) discuss the similar, Dutch Disease, impact of natural resource revenue gains. International transfer like remittances and foreign aid also act like inflows of natural resource revenue. The two effects, spending and resource reallocation to the non-traded sector, can shrink the traded (agricultural or manufacturing sectors).

Krugman (1987) explains that inflows of international transfers like natural resource revenue appreciates real exchange rate and some of the traded sector lose competitiveness and move abroad. If the transfer does not last long, external competitiveness is regained, but long lasting and substantial transfers erodes international competitiveness in some tradable sectors permanently. In that case, both merchandise export market share and international competitiveness decline. Thus, temporary resource booms cause a permanent loss of competitiveness. For developing countries, this means that their future potential for exporting manufactured goods and diversifying the production base is stunted. If there are positive externalities from human-capital accumulation in manufacturing only, as in Matsuyama (1992), and transfers retard the development of the more dynamic manufacturing sector, the growth path of the economy under free trade is lower than that of other countries.

Lopez, Monila and Bussolo (2008) explain that international transfers especially remittances can appreciate the real exchange rate firstly, by increasing the net foreign asset position of the remittance receiving country in relation to rest of the world. Secondly, changes in sectoral productivity can also take place. Remittances induce demand for non-tradables, redirecting labour there from the traded sector, thereby increasing relative real wages in the tradable sector. This differential leads to real exchange rate appreciation (Ballasa-Samuelson effect).

Acosta et al. (2009) find Dutch Disease impacts of remittances in El Salvador. Amuedo-Dorantes and Pozo (2004) find Dutch Disease symptoms caused by remittances, appreciating the real exchange rate in 13 Latin American and Caribbean countries. Lartey et al. (2012) find remittances induced Dutch Disease in a panel of 109 developing countries that operate more strongly under fixed exchange rates. Bourdet and Falck (2007) find less strong adverse effect of remittances on the competitiveness of tradables. In South Asian countries, Dutch Disease symptoms have also been evident. Chowdhury and Rabbi (2013) show that workers' remittances cause real exchange rate appreciation in Bangladesh, which in turn causes loss of competitiveness in export markets. Mughal and Makhlouf (2013) find Dutch Disease effects of re- 
mittances in the economy of Pakistan. On the other hand, Ratha (2013) does not find any Dutch Disease symptoms in India.

By contrast, Nyoni (1998) finds that foreign aid depreciates the real exchange in Tanzania. Martins (2013) does not find any Dutch Disease phenomenon in the Ethiopian economy. Barajas et al. (2011) explain that the impact of remittances on equilibrium real exchange rate comes through variety of macroeconomic channels. It depends on the remittance-receiving country's characteristics, pattern of remittance inflows (cyclical or not), long-run investment position induced by remittance inflows, and utilization of remittances (whether spent on non-traded or traded goods). The authors find mixed evidence of remittances on equilibrium real exchange rate in both single-country and a panel setting.

Foreign aid was thought to bridge the gap between demand and supply of capital in developing countries. However, to reap the benefits of aid presence of some good policies is very much important. Burnside and Dollar (2000) find that foreign aid is effective in accelerating growth of GDP in developing countries with good fiscal, monetary and trade policies. If aid is not channeled into investment rather than consumption, it causes a rise in the relative price of non-tradables, thereby appreciating real exchange rate. Rajan and Subramanian (2006), with a cross country panel data analysis, show that one percentage point increase in the ratio of aid-to-GDP is associated with $0.2-0.3$ percentage point reduction in the share of manufacturing sector to total GDP. Prati and Tressel (2006) find similar negative effects of aid on overall export sector. Empirical evidence of aid induced Dutch Disease is thus mixed. Countries where aid is used as investment and aid raises productivity in nontradables there is no Dutch Disease effect, whereas countries where aid induces consumption of more non-tradable goods and services there is a Dutch Disease effect. Effects of international transfers on growth of manufacturing sector also found mixed. Rajan and Subramanian (2011) find a negative impact of foreign aid on the growth rate of manufacturing sector in 47 developing countries whereas, Dzansi (2013) finds positive effects of remittances on the growth of manufacturing sector in a number of remittance dependent economies.

\section{Methodology and Data}

This study attempts to examine the relationship between external inflows (remittances and foreign aid) and the real exchange rate (REER), as well as changes in the relative composition of output between traded and nontraded goods. Consequently, we run two separate regressions: one for the Spending Effect, the other capturing the Resource Reallocation Effect.

\section{Spending effect equation:}


$\operatorname{REER}_{\text {it }}=\beta_{0}+\beta_{1} \mathrm{REM}_{\mathrm{it}}+\beta_{2} \mathrm{ODA}_{\mathrm{it}}+\beta_{3} \mathrm{FDI}_{\mathrm{it}}+\beta_{4} \mathrm{OPEN}_{\mathrm{it}}+\beta_{5} \mathrm{TOT}_{\mathrm{it}}+\beta_{6}$

GOVEX $_{\mathrm{it}}+\beta_{7}$ GDPPC $+\beta_{8} \mathrm{M} 2+\gamma_{\mathrm{t}}+\mathrm{v}_{\mathrm{i}}+\mathrm{e}_{\mathrm{it}}$

\section{Resource reallocation equation:}

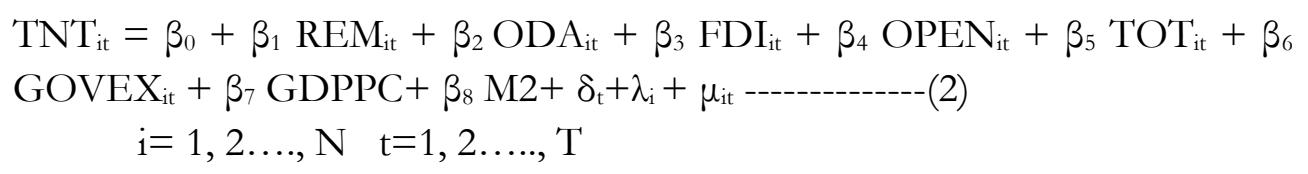

Where,

REER $=$ Real Effective Exchange Rate

REM = Migrant's Remittances (percent of GDP/ per capita)

ODA $=$ Net Official Development Assistance and official aid received (percent of GDP/ per capita)

FDI $=$ Net Foreign Direct Investment (percent of GDP)

OPEN $=$ Trade Openness (sum of exports and imports as percent of GDP)

TOT $=$ Net Barter Terms of Trade

GOVEX $=$ General government final consumption expenditure (percent of GDP)

GDPPC= GDP per capita (current US \$)

M2= Money and quasi money (percent of GDP)

$\gamma_{\mathrm{t}}$ and $\delta_{\mathrm{t}}=$ Time fixed effect

$\mathrm{v}_{\mathrm{i}}$ and $\lambda_{\mathrm{i}}=$ Time invariant country fixed effect

$\mathrm{e}_{\mathrm{it}}$ and $\mu_{\mathrm{it}}=$ error terms

Details on the data sources and definitions are given in the appendix. From the theoretical perspective (Corden and Neary 1982, Krugman 1987) it is evident that inflows of remittances may act like inflows of natural resource revenues, which may appreciate the real exchange rate. Therefore, a positive sign for remittances (REM) in equation (1) is expected. In order to control for non-linearties in this mechanism we will also incorporate the square of the remittance to GDP ratio. Foreign Aid/ODA is an international transfer like remittances. Thus, a positive sign for Aid/ODA is expected in equation (1) as well. Similarly, large FDI inflows appreciate REER.

According to the Balassa-Samuelson Hypothesis (see Balassa 1964 and Samuelson 1964), differences in productivity may have implications for the 
REER appreciation. To capture this effect we have employed GDP per capita for each country as a proxy for productivity differentials (see AmuedoDorantes and Pozo 2004). We expect that countries with higher GDP per capita (GDPPC) to experience REER appreciation. Therefore a positive sign is expected in equation (1) for this variable.

Government expenditure can change the relative price of non-tradables which can influence REER in turn. If the expenditures fall disproportionately on the non-traded sector, then prices of non-tradables will increase which will appreciate the REER (Froot and Rogoff 1995, as cited in Amuedo-Dorantes and Pozo 2004). But if it falls disproportionately on the traded sector, then it will depreciate the REER (Montiel 1999:279, as cited in Amuedo-Dorantes and Pozo 2004).

External terms of trade (TOT) may influence the REER. If relative wages in tradables increase without a rise in labour productivity, it will appreciate REER. Therefore, we expect positive sign for TOT in equation (1).

Trade openness (OPEN) has been included to capture the effect of trade restrictions on REER determination. An increase in import tariff reduces income, which in turn reduces demand for all goods and services. A fall in demand for non-tradables will reduce prices and, thereby depreciating REER (Lartey et al. 2012).On the other hand, the substitution effect induces a switch to non-tradables from imported goods after an increase in import tariff, causing prices of non-tradables to rise leading to REER appreciation (Edwards 1989, as cited in Lartey et al. 2012).Therefore, in equation (1) either a negative or positive association is expected. Broad money (M2) may cause real exchange rate appreciation through increased money supply and the associated inflation. A positive sign is expected for M2 in the equation (1).

The variables which are expected to have positive signs in equation (1) are likely to have negative signs in equation (2). This is because a real exchange rate appreciation will cause the traded to non-traded ratio to diminish.

\section{Estimation and Analysis}

We consider annual panel data from Bangladesh, India, Nepal, Pakistan, Sri Lanka, Bhutan, Maldives and Afghanistan spanning the period from 1975 to 2013. Data for all variables are not available for all these 38 years and for all countries leading to an unbalanced panel.

We estimated pooled OLS, and also fixed effect models to control for time invariant country fixed effects and time fixed effects. After performing the Hausman test we found that fixed effect model is preferred to the random 
effect model. One of our main variables of interest, remittances, may pose endogeneity issues. To rectify this problem, we adopt an Instrumental Variable (IV) approach to find the true impact of remittances on REER.

\section{Pooled OLS Estimation of REER}

Firstly, we have pooled all yearly data for 8 countries over different years spanning from the period of 1975-2013. We have considered both Driscoll-Kraay (DK) and Cluster-Robust (CR) standard errors. In the case of macro panel (long time dimensions and short cross-sections) DK based estimates are more efficient than the CR based estimates, as 'DK standard errors are heteroskedasticity consistent and robust to general forms of cross-sectional (spatial) and temporal dependence when the time dimension becomes large' (Hoechle 2007: 286).

Our data set is an unbalanced macro panel consisting of only 8 countries (cross sections) and on average a time period of 30 years. The data suffer from the presence of heteroskedasticy, cross sectional dependency (error terms of cross sections are dependent) and autocorrelation. In that case clusterrobust standard errors will give inefficient estimates, whereas Driscoll-Kraay standard error will give more efficiency. In table 2 we see that under DK and CR standard errors estimations values of coefficients are all the same but values of standard errors are slightly higher in DK estimation.

Table 2 reports regression results of the relation between real effective exchange rate and our main variables of interest (remittances and foreign aid). In all specifications both remittances as percent of GDP and remittances as per capita have the expected positive sign and are statistically highly significant. This indicates that remittances appreciate REER. If we were to drop Bhutan, Maldives and Afghanistan from the sample, the coefficient becomes smaller (0.027). The squared term on the remittances to GDP ratio is negative and highly significant, indicating a non-linearity in this process. This means that after a threshold, which we identify to be $14.64 \%$ of GDP remittances begin to depreciate the REER. This may be because of some initial REER overappreciation. Alternatively, the non-linearity may indicate that other factors become more salient, such as a substantial merchandise export decline causing balance of payments problems, eventually driving these economies to regain international competitiveness via depreciating real exchange rates. Foreign aid (ODA), in both measures (percent of GDP and per capita), has a negative sign and is statistically highly significant, indicating that aid depreciates REER. 
Table 2: Pooled OLS estimates of REER, with Driscoll-Kraay and cluster-robust Standard Errors

\begin{tabular}{|c|c|c|c|c|c|c|}
\hline \multicolumn{7}{|c|}{ Dependent variable : Log of Real Effective Exchange Rate(REER) } \\
\hline Regressors & $\begin{array}{l}\text { With Driscc } \\
(1)\end{array}$ & $\begin{array}{l}\text { I-Kraay Sta } \\
(2)\end{array}$ & $\begin{array}{l}\text { ard Error } \\
\text { (3) }\end{array}$ & $\begin{array}{l}\text { With Clust } \\
(4)\end{array}$ & $\begin{array}{l}\text { r-Robust S } \\
(5)\end{array}$ & $\begin{array}{l}\text { Standard Error } \\
(6)\end{array}$ \\
\hline Remittances $(\%$ of GDP) & $\begin{array}{l}0.205^{* * *} \\
(0.029)\end{array}$ & & & $\begin{array}{l}0.205^{* * *} \\
(0.027)\end{array}$ & & $\begin{array}{l}0.205^{* * *} \\
(0.029)\end{array}$ \\
\hline Remittances $(\%$ of GDP) squared & $\begin{array}{l}-0.007 * * * \\
(0.001)\end{array}$ & & & $\begin{array}{l}-0.007 * * * \\
(0.001)\end{array}$ & & $-0.007 * * *$ \\
\hline Log Remittances (per capita) & & $\begin{array}{l}0.495^{* * *} \\
(0.059)\end{array}$ & $\begin{array}{l}0.522 * * * \\
(0.045)\end{array}$ & & $\begin{array}{l}0.495^{* * *} \\
(0.041)\end{array}$ & $\begin{array}{l}0.522 * * * \\
(0.036)\end{array}$ \\
\hline ODA ( Net ODA + Official aid \% of GDP) & $\begin{array}{l}-0.052^{* * *} \\
(0.003)\end{array}$ & $\begin{array}{l}-0.056^{* * *} \\
(0.002)\end{array}$ & & $\begin{array}{l}-0.052 * * * \\
(0.003)\end{array}$ & $\begin{array}{l}-0.056^{* * *} \\
(0.003)\end{array}$ & \\
\hline Log ODA (Net ODA+ Official aid per capita) & & & $\begin{array}{l}-0.344 * * * \\
(0.062)\end{array}$ & & & $\begin{array}{l}-0.344 * * * \\
(0.048)\end{array}$ \\
\hline Foreign Direct Investment ( $\%$ of GDP) & $\begin{array}{l}-0.030 \\
(0.061)\end{array}$ & $\begin{array}{l}0.022 \\
(0.042)\end{array}$ & $\begin{array}{l}0.011 \\
(0.037)\end{array}$ & $\begin{array}{l}-0.030 \\
(0.079)\end{array}$ & $\begin{array}{l}0.022 \\
(0.055)\end{array}$ & $\begin{array}{l}0.011 \\
(0.044)\end{array}$ \\
\hline Log terms of trade (TOT) & $\begin{array}{l}0.129 \\
(0.263)\end{array}$ & $\begin{array}{l}0.240 \\
(0.265)\end{array}$ & $\begin{array}{l}-0.055 \\
(0.066)\end{array}$ & $\begin{array}{l}0.129 \\
(0.129)\end{array}$ & $\begin{array}{l}0.240^{* *} \\
(0.118)\end{array}$ & $\begin{array}{l}-0.055 \\
(0.113)\end{array}$ \\
\hline Log trade openness $(\mathrm{X}+\mathrm{M}$ as $\%$ of GDP $)$ & $\begin{array}{l}-0.516^{* * *} \\
(0.181)\end{array}$ & $\begin{array}{l}-0.502^{* * *} \\
(0.126)\end{array}$ & $\begin{array}{l}-0.256^{* *} \\
(0.099)\end{array}$ & $\begin{array}{l}-0.516^{* * *} \\
(0.107)\end{array}$ & $\begin{array}{l}-0.502^{* * *} \\
(0.082)\end{array}$ & $\begin{array}{l}-0.256^{* * *} \\
(0.096)\end{array}$ \\
\hline Government Expenditure ( $\%$ of GDP) & $\begin{array}{l}-0.011 \\
(0.008)\end{array}$ & $\begin{array}{l}0.005 \\
(0.009)\end{array}$ & $\begin{array}{l}0.005 \\
(0.012)\end{array}$ & $\begin{array}{l}-0.011 \\
(0.009)\end{array}$ & $\begin{array}{l}0.005 \\
(0.007)\end{array}$ & $\begin{array}{l}-0.011 \\
(0.008)\end{array}$ \\
\hline M2 (\% of GDP) & $\begin{array}{l}-0.003 \\
(0.003)\end{array}$ & $\begin{array}{l}-0.009 * * * \\
(0.003)\end{array}$ & $\begin{array}{l}-0.016^{* * *} \\
(0.004)\end{array}$ & $\begin{array}{l}-0.003 \\
(0.003)\end{array}$ & $\begin{array}{l}-0.009 * * * \\
(0.002)\end{array}$ & $\begin{array}{l}-0.016^{* * *} \\
(0.002)\end{array}$ \\
\hline Log per capita GDP & $\begin{array}{l}-0.296^{*} \\
(0.161)\end{array}$ & $\begin{array}{l}-0.731 \text { *** } \\
(0.113)\end{array}$ & $\begin{array}{l}-0.548^{* * *} \\
(0.088)\end{array}$ & $\begin{array}{l}-0.296^{* * *} \\
(0.102)\end{array}$ & $\begin{array}{l}-0.731 \text { *** } \\
(0.085)\end{array}$ & $\begin{array}{l}-0.548^{* * *} \\
(0.075)\end{array}$ \\
\hline Constant & $\begin{array}{l}7.404 * * * \\
(1.741)\end{array}$ & $\begin{array}{l}8.922^{* * *} \\
(1.573)\end{array}$ & $\begin{array}{l}9.078^{* * *} \\
(0.792)\end{array}$ & $\begin{array}{l}7.404 * * * \\
(0.931)\end{array}$ & $\begin{array}{l}8.922 * * * \\
(0.808)\end{array}$ & $\begin{array}{l}9.078^{* * *} \\
(0.653)\end{array}$ \\
\hline Observations & 167 & 167 & 167 & 167 & 167 & 167 \\
\hline R-squared & 0.841 & 0.901 & 0.851 & 0.841 & 0.901 & 0.851 \\
\hline Number of countries & 8 & 8 & 8 & 8 & 8 & 8 \\
\hline
\end{tabular}

However, the pooled OLS estimates may be biased and inconsistent as we have not controlled for the country and time fixed effects. Time-invariant unobservable country characteristics might be correlated with the explanatory variables. Country fixed characteristics and time variable may also be important determinants of REER. In addition, remittances are not purely exogenous. In the next section, we will perform instrumental variable fixed effect estimates addressing endogeneity and controlling for time-invariant country effects and time fixed effect.

\section{Instrumental Variable (IV) Fixed Effect Estimation of REER}

There may be a reverse causality between remittances and REER. On the one hand, REER depends on remittance inflows; on the other hand, remittance inflows may depend on the level of REER. Remittances could also be procyclical and counter cyclical. If remittances are sent as capital for investment motives, in the good time of the remittances receiving economy there will be more remittance inflows (procyclical), and vice versa. On the other 
hand, if remittances are sent for altruistic reasons, remittance inflows increase during economic downturns (countercyclical). Therefore, in literature it is argued that remittances are endogenous (see Acosta et al. 2009, AmuedoDorantes and Pozo 2004, Lartey et al. 2012).

To remove the problem of potential endogeneity one can opt for instrumental variable and system GMM techniques. But in our case system GMM will not be efficient since the data set is a macro panel, large $T$ and small $\mathrm{N}$ (Roodman 2009). That is why we adopt the IV technique only. In literature various instruments for remittances have been proposed, such as school enrollment rate, crop and livestock production index, immunization index, literacy rate, economic condition of host countries, distance between migrant sending and receiving countries, stock and flow of migrants, population density, unemployment rate in sending country etc. We have performed IV fixed effect regression using crop production index and primary school enrollment rate as instruments, following Amuedo-Dorantes and Pozo (2004). Hausman tests suggest that the random effects model is a less efficient estimator. It is expected that volume of remittances will be higher with a low value of crop production and low level of primary school enrollment, and vice versa. Most of the remittances earners in South Asian countries are unskilled or semiskilled workers, and they have low levels of schooling or no schooling at all. Surplus labour in agriculture, compels surplus workers to look for jobs elsewhere, putting pressure on labour markets in informal sectors. Thus, a low level of agricultural production and school enrollment will increase out migration, thereby increasing the volume of remittances.

We find negative signs for both crop production index and school enrollment ratio in the first stage IV regression for remittances. Coefficients of instruments are statistically significant at conventional levels. Both of the instruments passed the test of under identification. Kleibergen-Paap rk LM statistics is statistically significant, which rejects the null of under identification. However, the crop production index does not pass the weak instrument test, whereas the primary school enrollment ratio is a strong instrument if 3 countries: Afghanistan, Bhutan and Maldives are excluded; the previously reliable Kleibergen-Paap Wald rk F statistic diminishes substantially with their inclusion. Results of first stage IV fixed effect regression are presented in table 3, and results of second stage IV fixed effect estimation are presented in table 4. Due to the lack of an instrument for the square of remittances/GDP, we do not experiment with a squared term in table 4 .

(Continued on next page) 
Table 3: First stage IV Fixed Effect estimates of REER

Dependent variable is Log remittances per capita

\begin{tabular}{lll}
\hline Regressors & IV -1 & IV -2 \\
\hline
\end{tabular}

Log crop production index

$-1.019 *$

0.547

Log primary school enrollment ratio

$-1.344 * *$

Log ODA (Net ODA+ Official aid per capita)

0.059

0.074

$(0.170)$

Foreign Direct Investment ( $\%$ of GDP)

$-0.082 * * *$

$(0.173)$

Log terms of trade (TOT)

$-0.150$

$-0.342$

(0.165)

Log trade openness

0.382

0.279

$(0.262)$

$(0.351)$

Government Expenditure ( \% of GDP)

0.031

0.040

M2 (\% of GDP)

$(0.025)$

$(0.051)$

$0.028 * * *$

$0.033^{* * *}$

(0.010)

$(0.010)$

Log per capita GDP

0.749

0.596

(0.386)

(0.617)

Observations

167

137

Kleibergen-Paap rk LM statistic (P value)

0.046

0.0379

Kleibergen-Paap Wald rk F statistic

3.48

5.18

Notes: Driscoll-Kraay standard errors are in parenthesis. Driscoll-Kraay standard errors are robust to heteroskedasticity, cross sectional dependence and autocorrelation. Asterisk ***,**,* indicates significance at 1,5 and 10\% level, respectively. Regressions contain time-fixed effects. IV-1 = Log crop production index, IV-2 = Primary school enrollment ratio. 
Table 4: Second stage IV Fixed-Effects estimates of REER

\begin{tabular}{|c|c|c|}
\hline \multicolumn{3}{|c|}{ Dependent variable is Log of Real Effective Exchange Rate(REER) } \\
\hline Regressors & IV-1 & IV-2 \\
\hline \multirow[t]{2}{*}{ Log Remittances (per capita) } & $0.457 *$ & $0.191^{*}$ \\
\hline & $(0.263)$ & $(0.110)$ \\
\hline \multirow[t]{2}{*}{ Log ODA (Net ODA+ Official aid per capita) } & 0.010 & 0.085 \\
\hline & $(0.067)$ & $(0.071)$ \\
\hline \multirow{2}{*}{ Foreign Direct Investment ( $\%$ of GDP) } & 0.041 & 0.003 \\
\hline & $(0.043)$ & $(0.040)$ \\
\hline \multirow[t]{2}{*}{ Log terms of trade (TOT) } & -0.115 & $-0.231 * * *$ \\
\hline & $(0.104)$ & $(0.069)$ \\
\hline \multirow{2}{*}{ Log trade openness } & -0.264 & -0.070 \\
\hline & $(0.175)$ & $(0.129)$ \\
\hline \multirow[t]{2}{*}{ Government Expenditure ( $\%$ of GDP) } & -0.005 & 0.002 \\
\hline & $(0.014)$ & $(0.012)$ \\
\hline \multirow{2}{*}{ M2 ( $\%$ of GDP) } & -0.004 & 0.001 \\
\hline & $(0.007)$ & $(0.005)$ \\
\hline \multirow[t]{2}{*}{ Log per capita GDP } & 0.410 & $0.788^{* * *}$ \\
\hline & $(0.320)$ & $(0.168)$ \\
\hline Observations & 167 & 137 \\
\hline R-squared & 0.512 & 0.716 \\
\hline Number of countries & 8 & 8 \\
\hline Country fixed effect & Yes & Yes \\
\hline Time fixed effect & Yes & Yes \\
\hline
\end{tabular}

Like with the pooled OLS remittances also appear with a positive sign in the IV fixed effect estimation. Remittances are statistically significant at 1 percent level. Foreign aid (ODA) has the same negative sign as in pooled OLS, but here it is not statistically significant at any conventional level. Therefore, foreign aid (ODA) does not have any effect on the REER determination. Coefficients of remittances differ under the two instruments. With the crop production index the coefficient is larger than with the primary school enrollment, the latter being more acceptable.

One may question the validity of REER appreciation if the countries follow fixed exchange or managed exchange rate regimes. Under fixed exchange rate regime, there will be little direct impact of remittances and foreign aid on nominal exchange rates but will lead to reserve accumulation. Most South Asian countries pursue fixed or managed exchange rates. Bangladesh, 
Pakistan and Sri Lanka have effectively fixed exchange rate regimes, while India has a managed floating exchange rate regime (Cavoli and Rajan 2013).

REER determination depends not only on nominal exchange rate but also on price levels. With a fixed exchange rate regime an exogenous increase in international transfers increases general price levels, thus appreciating REER. However, with flexible exchange rate regime, real appreciation happens quickly through nominal exchange rate appreciation. Under a fixed exchange rate regime real appreciation takes place in the longer run, but the outcome could be greater. Lartey et al. (2012) investigate Dutch Disease impact of foreign remittances in countries under both fixed and flexible exchange rate regimes. They find stronger Dutch Disease impact in countries under fixed nominal exchange rate regimes. Similarly, Fielding and Gibson (2012) find a stronger Dutch Disease impact of foreign aid on countries under fixed exchange rate regimes.

\section{Pooled OLS Estimation of Traded to Non-Traded Sector Ra- tio (TNT)}

Results of pooled OLS regressions of TNT for different specifications are presented in table 5. Remittances to GDP, has the expected negative sign and is statistically significant at $10 \%$ level of significance. The coefficient on of the squared term for remittances is very small (0.001), and is significant at the $10 \%$ level. Coefficients on foreign aid as percent of GDP and as per capita, have unexpectedly positive signs. However, remittances as per capita is only is significant at a $5 \%$ level.

(Continued on next page) 
Table 5: Pooled OLS estimates of Traded to Non-Traded ratio (TNT)

\begin{tabular}{|c|c|c|c|}
\hline \multicolumn{4}{|c|}{ Dependent variable is Traded to Non-Traded ratio (TNT) } \\
\hline Regressors & (1) & (2) & (3) \\
\hline \multirow[t]{2}{*}{ Remittances ( $\%$ of GDP) } & $-0.018^{*}$ & & \\
\hline & $(0.010)$ & & \\
\hline \multirow[t]{2}{*}{ Remittances ( $\%$ of GDP) squared } & $0.001^{*}$ & & \\
\hline & $(0.000)$ & & \\
\hline \multirow[t]{2}{*}{ Log Remittances (per capita) } & & -0.018 & -0.017 \\
\hline & & $(0.021)$ & $(0.022)$ \\
\hline \multirow[t]{2}{*}{ ODA ( Net ODA+ Official aid \% of GDP) } & 0.001 & 0.001 & \\
\hline & $(0.002)$ & $(0.002)$ & \\
\hline \multirow[t]{2}{*}{ Log ODA (Net ODA+ Official aid per capita) } & & & $0.028^{* *}$ \\
\hline & & & $(0.011)$ \\
\hline \multirow[t]{2}{*}{ Foreign Direct Investment ( $\%$ of GDP) } & -0.025 & -0.025 & -0.021 \\
\hline & $(0.020)$ & $(0.019)$ & $(0.019)$ \\
\hline \multirow[t]{2}{*}{ Log terms of trade (TOT) } & -0.022 & -0.021 & -0.013 \\
\hline & $(0.047)$ & $(0.050)$ & $(0.059)$ \\
\hline \multirow[t]{2}{*}{ Log trade openness $(\mathrm{X}+\mathrm{M}$ as $\%$ of GDP) } & -0.012 & -0.026 & $-0.067^{*}$ \\
\hline & $(0.027)$ & $(0.028)$ & $(0.035)$ \\
\hline \multirow[t]{2}{*}{ Government Expenditure ( $\%$ of GDP) } & $0.011^{* *}$ & $0.012^{* *}$ & $0.012^{* *}$ \\
\hline & $(0.005)$ & $(0.005)$ & $(0.005)$ \\
\hline \multirow[t]{2}{*}{ M2 ( \% GDP) } & 0.000 & 0.001 & $0.002^{*}$ \\
\hline & $(0.001)$ & $(0.001)$ & $(0.001)$ \\
\hline \multirow[t]{2}{*}{ Log GDP per capita } & $-0.275^{* * *}$ & $-0.261 * * *$ & $-0.270^{* * *}$ \\
\hline & $(0.055)$ & $(0.051)$ & $(0.056)$ \\
\hline \multirow[t]{2}{*}{ Constant } & $2.641 * * *$ & $2.562^{* * *}$ & $2.631^{* * *}$ \\
\hline & $(0.419)$ & $(0.398)$ & $(0.425)$ \\
\hline Observations & 167 & 167 & 167 \\
\hline R-squared & 0.710 & 0.702 & 0.710 \\
\hline Number of countries & 8 & 8 & 8 \\
\hline
\end{tabular}


Country fixed effects and time variables may have significant effects on the TNT ratio.

\section{Fixed-Effect Estimation of Traded to Non-Traded Sector Ra- tio (TNT)}

Results of fixed effect estimates of TNT for different specifications are presented in table 6 .

Table 6: Fixed-Effect estimates of Traded to Non-Traded ratio (TNT)

\begin{tabular}{|c|c|c|c|}
\hline \multicolumn{4}{|c|}{ Dependent variable is Traded to Non-Traded ratio (TNT) } \\
\hline Regressors & $(1)$ & $(2)$ & (3) \\
\hline Remittances ( $\%$ of GDP) & $\begin{array}{l}-0.016 * * \\
(0.006)\end{array}$ & & \\
\hline Remittances ( $\%$ of GDP) squared & $\begin{array}{l}0.000 \\
(0.000)\end{array}$ & & \\
\hline Log Remittances (per capita) & & $\begin{array}{l}-0.082^{*} \\
(0.038)\end{array}$ & $\begin{array}{l}-0.086^{*} \\
(0.038)\end{array}$ \\
\hline $\begin{array}{l}\text { ODA ( Net ODA+ Official aid } \% \text { of } \\
\text { GDP) }\end{array}$ & $0.010^{*}$ & 0.008 & \\
\hline $\begin{array}{l}\text { Log ODA (Net ODA+ Official aid per } \\
\text { capita) }\end{array}$ & $(0.004)$ & $(0.006)$ & $0.050^{*}$ \\
\hline Foreign Direct Investment ( $\%$ of GDP) & $\begin{array}{l}0.001 \\
(0.006)\end{array}$ & $\begin{array}{l}0.002 \\
(0.009)\end{array}$ & $\begin{array}{l}(0.024) \\
0.001 \\
(0.010)\end{array}$ \\
\hline Log terms of trade (TOT) & $\begin{array}{l}-0.090^{* *} \\
(0.027)\end{array}$ & $\begin{array}{l}-0.013 \\
(0.018)\end{array}$ & $\begin{array}{l}-0.005 \\
(0.019)\end{array}$ \\
\hline Log trade openness $(\mathrm{X}+\mathrm{M}$ as $\%$ of GDP) & $\begin{array}{l}-0.052 \\
(0.031)\end{array}$ & $\begin{array}{l}0.005 \\
(0.029)\end{array}$ & $\begin{array}{l}0.042 \\
(0.036)\end{array}$ \\
\hline Government Expenditure ( $\%$ of GDP) & $\begin{array}{l}-0.002 \\
(0.006)\end{array}$ & $\begin{array}{l}-0.001 \\
(0.005)\end{array}$ & $\begin{array}{l}-0.002 \\
(0.004)\end{array}$ \\
\hline M2 ( \% GDP) & $\begin{array}{l}-0.001 \\
(0.001)\end{array}$ & $\begin{array}{l}-0.003^{*} \\
(0.001)\end{array}$ & $\begin{array}{l}-0.003 * \\
(0.001)\end{array}$ \\
\hline Log GDP per capita & $\begin{array}{l}0.007 \\
(0.171)\end{array}$ & & \\
\hline GDP Growth & & $\begin{array}{l}0.003 \\
(0.005)\end{array}$ & $\begin{array}{l}0.003 \\
(0.005)\end{array}$ \\
\hline Constant & $\begin{array}{l}1.711^{* *} \\
(0.535)\end{array}$ & $\begin{array}{l}1.594 * * * \\
(0.221)\end{array}$ & $\begin{array}{l}1.498^{* * *} \\
(0.173)\end{array}$ \\
\hline Observations & 167 & 165 & 165 \\
\hline R squared (within) & 0.853 & 0.854 & 0.854 \\
\hline Number of countries & 8 & 8 & 8 \\
\hline Country fixed effect & Yes & Yes & Yes \\
\hline Time fixed effect & Yes & Yes & Yes \\
\hline
\end{tabular}


Like with pooled OLS, remittances appear statistically significant with a negative sign, and foreign aid (ODA) has a positive sign. The squared term for remittances is zero and insignificant. These findings reflect that remittances affect the composition of traded and non-traded sector, and foreign aid does not have any negative impact. Time fixed effects and country fixed characteristics might have a bearing on these results, making aid statistically insignificant in the fixed effect model. Table 7 presents summary findings related to two dependent variables using two different models.

Table 7: Estimates of REER and TNT, Pooled OLS and Fixed Effect models

\begin{tabular}{|c|c|c|c|c|}
\hline \multicolumn{5}{|c|}{ Dependent variable is log of Real Effective Exchange Rate (REER) and TNT } \\
\hline \multirow[b]{3}{*}{ Regressors } & \multicolumn{2}{|c|}{ REER } & \multicolumn{2}{|c|}{ TNT } \\
\hline & (1) & (2) & (3) & (4) \\
\hline & Pooled & IV-2 FE & Pooled & FE \\
\hline \multirow[t]{2}{*}{ Remittances ( $\%$ of GDP) } & $0.205^{* * *}$ & & $-0.018^{*}$ & $-0.016^{* *}$ \\
\hline & $(0.029)$ & & $(0.010)$ & $(0.006)$ \\
\hline \multirow{2}{*}{ Remittances ( $\%$ of GDP) squared } & $-0.007 * * *$ & & $0.001 *$ & 0.000 \\
\hline & $(0.001)$ & & $(0.000)$ & $(0.000)$ \\
\hline \multirow{2}{*}{ Log Remittances (per capita) } & & $0.191 *$ & & \\
\hline & & $(0.110)$ & & \\
\hline \multirow{2}{*}{$\begin{array}{l}\text { ODA ( Net ODA+ Official aid \% } \\
\text { of GDP) }\end{array}$} & $-0.052^{* * *}$ & & 0.001 & $0.010^{*}$ \\
\hline & $(0.003)$ & & $(0.002)$ & $(0.004)$ \\
\hline Log ODA (per capita) & & $\begin{array}{l}0.085 \\
(0.071)\end{array}$ & & \\
\hline \multirow{2}{*}{$\begin{array}{l}\text { Foreign Direct Investment }(\% \text { of } \\
\text { GDP) }\end{array}$} & -0.030 & 0.003 & -0.025 & 0.001 \\
\hline & $(0.061)$ & $(0.040)$ & $(0.020)$ & $(0.006)$ \\
\hline \multirow[t]{2}{*}{ Log terms of trade (TOT) } & 0.129 & $-0.231 * * *$ & -0.022 & $-0.090^{* *}$ \\
\hline & $(0.263)$ & $(0.069)$ & $(0.047)$ & $(0.027)$ \\
\hline \multirow[t]{2}{*}{ Log trade openness } & $-0.516^{* * *}$ & -0.070 & -0.012 & -0.052 \\
\hline & $(0.181)$ & $(0.129)$ & $(0.027)$ & $(0.031)$ \\
\hline \multirow{2}{*}{$\begin{array}{l}\text { Government Expenditure ( } \% \text { of } \\
\text { GDP) }\end{array}$} & -0.011 & 0.002 & $0.011^{* *}$ & -0.002 \\
\hline & $(0.008)$ & $(0.012)$ & $(0.005)$ & $(0.006)$ \\
\hline \multirow[t]{2}{*}{ M2 ( $\%$ of GDP) } & -0.003 & 0.001 & 0.000 & -0.001 \\
\hline & $(0.003)$ & $(0.005)$ & $(0.001)$ & $(0.001)$ \\
\hline \multirow[t]{2}{*}{ Log per capita GDP } & $-0.296 *$ & $0.788^{* * *}$ & $-0.275^{* * *}$ & 0.007 \\
\hline & $(0.161)$ & $(0.168)$ & $(0.055)$ & $(0.171)$ \\
\hline Observations & 167 & 137 & 167 & 167 \\
\hline R-squared (within) & 0.841 & 0.716 & 0.710 & 0.853 \\
\hline Number of countries & 8 & 8 & 8 & 8 \\
\hline Country fixed effect & - & Yes & - & Yes \\
\hline
\end{tabular}


Based on the IV-2 fixed effect estimates (column 2) if per capita remittances increase by one percent, controlling for other factors, then on an average REER appreciates by 0.191 percent. Alternatively, if per capita remittances double, REER appreciates by 19.1 percent which is similar to AmuedoDorantes and Pozo's (2004) findings. They found that a doubling of per capita remittances raises real exchange rate by 23 percent in 13 Latin American countries. On the other hand, remittances (as percent of GDP) are negatively associated with the traded to non-traded sector ratio (TNT) and statistically significant at conventional levels in both pooled OLS and Fixed Effect models. Fixed effect estimates of TNT (column 4) show that a one percentage point increase in remittances to GDP leads to fall in traded to non-traded ratio by 0.016. Both the magnitudes of spending and resource movement effects are substantial and economically significant. These findings indicate the loss of international competitiveness, thereby reducing export volume, and contraction of the traded manufacturing sector. Over the period per capita remittances in South Asian countries increased manifold (in Bangladesh 13 times) and the service sector which is primarily non-tradable expanded substantially (in Bangladesh it expanded by almost 64 percent), whereas the manufacturing sector, relatively speaking, shrank.

Foreign aid (ODA), however, is largely statistically insignificant. It is negatively associated with REER and positively associated with TNT. However, in our case foreign aid has no statistically significant impact on real effective exchange rate appreciation and relative growth of non-traded sector.

Terms of trade in both the spending effect and resource allocation regressions is statistically significant and negatively associated with the real exchange rate and the traded to non-traded goods ratio under the fixed effect model. It indicates that the terms of trade exerts pressure on resources to relocate from the tradable to the non-tradable sectors. However, improvement in the terms of trade may cause a trade surplus leading to nominal exchange rate appreciation. To arrest the loss in international competitiveness due to nominal exchange rate appreciation, South Asian countries devalue their own currencies occasionally. This nominal exchange rate devaluation might be one of the reasons for the negative association between the terms of trade and REER.

No statistically significant linear dependence of REER and TNT on foreign direct investment was detected. Trade openness appears statistically significant in pooled OLS estimates of REER only. Broad money supply (M2) is not statistically significant in the fixed effect estimates of REER and TNT. 
Per capita GDP has statistically significant effect on REER and TNT in the fixed effect and pooled OLS models, respectively. It indicates that BallasaSamuelson hypothesis holds in the South Asia.

\section{Consequences of Dutch Disease}

Lopez, Monila and Bussolo (2008) mention three adverse impacts of real exchange rate appreciation caused by international transfers like remittances and foreign aid. First, a negative impact on the traded sector, reinforced by rising inflation and economy wide wages. The adverse impact may be magnified further if labour supply falls. Reservation wages in the remittances receiving households may increase or the returning migrant may attach higher value to leisure.

Secondly, any current account deficit may widen. If increased consumption demand induced by transfers is not covered by the non-tradables, import demand will increase. Due to the increase in import demand coupled with the fall in exports due to the loss in international competiveness, the current account balance will worsen.

If the international transfers do not go back abroad through increased imports, a large inflow will increase the money supply, and be inflationary. Also, prices of financial assets and real estate shoot up after a surge in remittances. This distorts the allocation of investment across different sectors.

Furthermore, and most importantly, because of Dutch Disease effects, developing countries may experience 'premature deindustrialization' (Rodrik, 2015). The term 'premature deindustrialization' was first coined by Dasgupta and Singh (cited in Rodrik, 2015). This term refers to vanishing competitiveness and deindustrialization, before a proper phase of manufacturing competitiveness. In most advanced industrialized countries at the earlier phase of the modern increased growth experience, the share of manufacturing value added in national income and the employment share of manufacturing rises at first, and then begins to decline with a mature economy; eventually services dominate both value added and employment shares. This points to an inverted $\mathrm{U}$ shaped relation between income per-capita and growth on the one hand and manufacturing value added and employment shares in the economy, a process driven by labour productivity increases in manufacturing. The process of the relative decline in manufacturing output and employment usually took several generations in the advanced developed countries. In contemporary developing countries, this process of the decline in manufacturing may be much faster than that experienced by the world's older developed economies, and certain regions, such as sub-Saharan Africa, may miss out on the industrialization experience altogether; see the evidence cited in Rodrik (2015). Globalisation factors leading to a fall in manufactures prices, coupled with a remittance induced 
prevention of productivity increases in manufacturing may hasten the process of premature deindustrialization.

Besides the loss of the dynamic gains in growth from a prolonged experience of manufacturing competitiveness, there are major adverse political consequences of premature deindustrialization. Historically, industrialization in the western societies shaped modern society; played a great role in establishing modern welfare states, promoting more egalitarian societies and the emergence of democratic institutions. Premature deindustrialization may therefore retard democratic development, the provision of social protection and public goods, as well as perpetuate inequality in the developing countries of today.

\section{Deindustrialization: South Asian Context}

Our discussion here is mainly confined to India, Pakistan, Bangladesh, Nepal and Sri Lanka for which data is more readily available. In South Asia over the period, services have been expanding, while the manufacturing sector has been shrinking in relative terms, as illustrated in Figure 5. In Nepal, manufacturing value added was almost 4 percent of GDP in the 1970s, reaching a peak of 9 percent in 1990s, and then started to fall in 2000s. In 2013, it was only 6.5 percent of GDP. Service sector value added grew to 49 percent of GDP in 2013. Value added in the manufacturing and service sectors followed the same pattern in Pakistan as well. Mughal (2013) analyzes how remittances can foster a remittance dependency mindset in the context of Pakistan; this could also be applicable to Bangladesh.

(Continued on next page) 
Figure 5: Manufacturing and services value added (\% of GDP) in South Asian countries

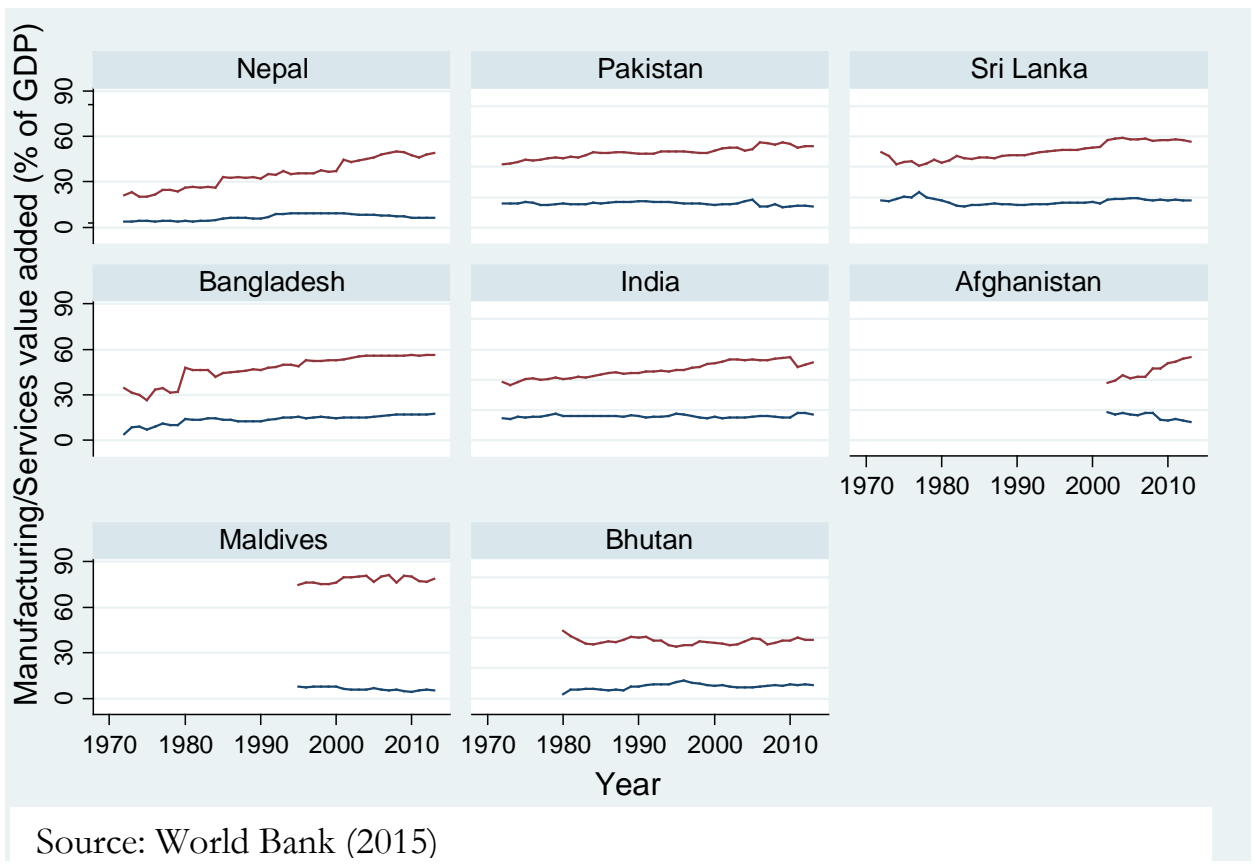

Manufacturing value added fluctuates between 14 to 15 percent of GDP over the period, whereas service sector value added reached 53.8 percent in 2013. Manufacturing value added in Sri Lanka was little higher than that of Pakistan (about 17 percent) but it also tends to fall after reaching a high of about 19 percent. In Bangladesh, manufacturing value added grew slowly from about 5 percent in 1970s to about 17 percent in 2010s. Manufacturing value added in India rose by 4 percentage points from 1972 to 2013, while the service sector value added increased by 13 percentage points during the period. 
Figure 6 illustrates employment in industry and service sectors for the period of 1972 to 2013 in South Asian countries. Over the period, there is an upward trend in employment in service sector and a downward trend in employment in industry. In Pakistan, employment in industry and service sector was 20.3 and 26.8 percent of total employment, respectively in 1980. Employment in industry fluctuated between 20-21 percent from the period of 1972 to 2013, while employment in service sector, with some ups and downs, increased over the period. Sri Lanka shows an upward trend for service sector employment and downward trend in industry employment. Bangladesh also shows a divergence between employment in industry and service sector. However, India shows convergence. But actual employment in manufacturing sector is lower as industry includes manufacturing along with mining, construction, and public utilities.

\section{Figure 6: Employment in industry and service sector in South Asian countries}

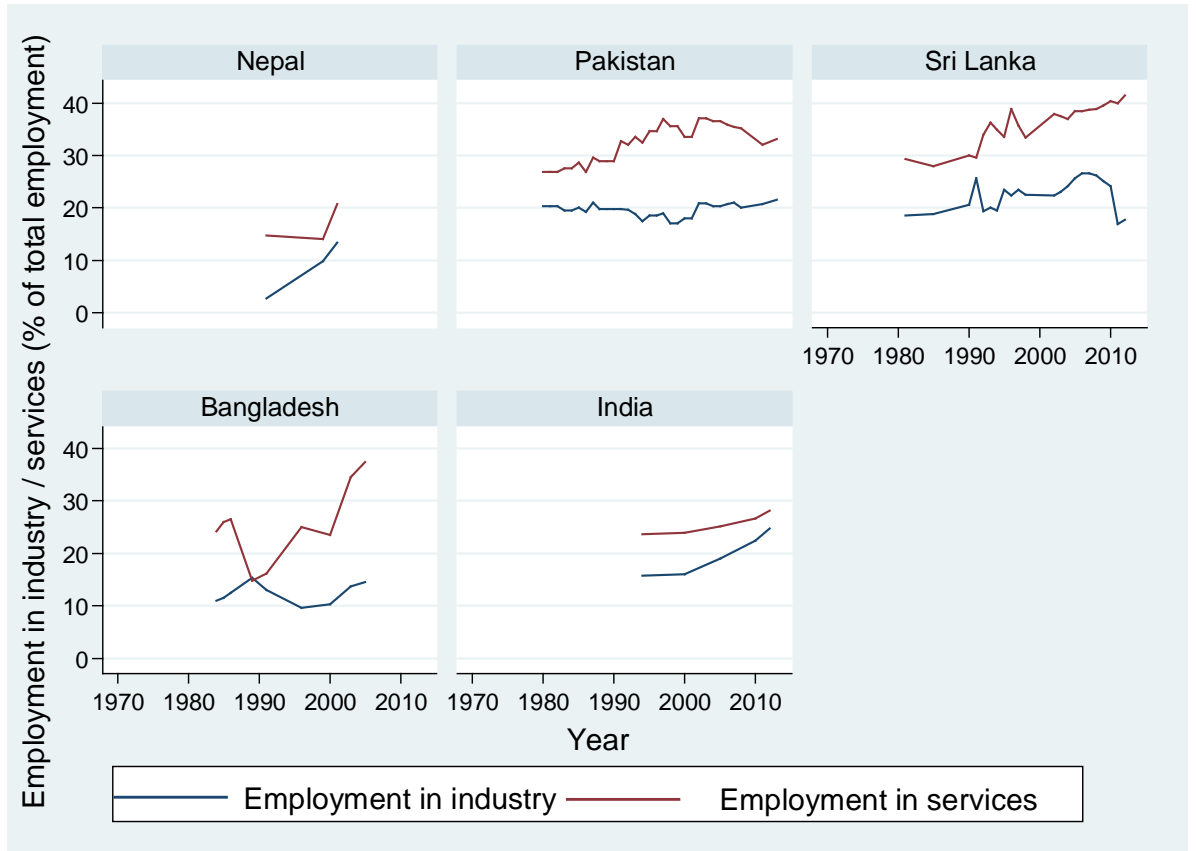

Source: World Bank (2015)

Amirapu and Subramanian (2015) term deindustrialization in India as 'premature non-industrialization' because India never experienced sufficient industrialization in the first place. The same applies to all other South Asian countries where service sector became large (almost $50 \%$ of GDP) and manufacturing sector starts to fall before reaching its peak. Also, there may be missing aspects of the structural changes in the production process, as expounded by Storm (2015). The structural change comes through stages -- firstly absorbing existing technology, then catching up with technologically advanced countries, and finally continuing manufacturing activities with accumulated knowledge; see 
Storm (2015). Migrant's remittances to South Asia might have been one of the stumbling blocks in the way of this type of structural transformation.

\section{Utilization of Remittances}

The lion's share of foreign remittances to South Asia is spent on consumption, whereas a meager share is spent on investment purposes. So far two household remittance surveys have been conducted in Bangladesh -- by the International Organization for Migration (IOM) in 2009, and by the Bangladesh Bureau of Statistics (BBS) in 2013. The IOM (2010) findings reveal that in most cases (80 percent) migrants send remittances primarily to meet family expenses and the second major purpose is paying off debt and celebration of religious festivals. In only a small number of cases ( 5 percent) remittances are spent on buying land/property. BBS (2014) findings reveal that at the national level about 84 percent of remittances received are spent, and the remainder saved. According to the Reserve Bank of India, more than half of the remittances to India are spent on family consumption, while the rest are either deposited in bank accounts (20 percent) or invested in land, property, and securities $(7$ percent, Afram 2012). According to the Nepal Living Standards Survey (2011), the major share (79 percent) of total remittances received by households are spent on daily household needs, while the rest are spent on loan repayments ( 7 percent), buying property ( 5 percent), education( 4 percent) and capital formation ( 2 percent). Pakistan also follows a similar pattern in using remittances. The IOM (2009) survey in Pakistan shows that half (50.21 percent) of remittances are used in consumption, and other half are used on buying real estate and agricultural machinery (22.12 percent), health(3.56), education (4.52), loan repayment (5.52) and savings (14.08). With this pattern of utilization, it can be concluded that remittances to South Asia fuel inflation and augment demand for non-tradables leading to real exchange rate appreciation and a reallocation of output towards services.

\section{Conclusion}

Based on the Salter-Swan-Corden-Neary framework this study has examined the Dutch Disease impact of migrant's remittances and foreign aid. We have used pooled OLS and fixed effect models with panel data for eight South Asian countries for the period from 1975 to 2013. We have employed two separate regressions to examine the spending effect as well as the resource reallocation effect. The spending effect impacts on the real effective exchange rate, whereas the resource reallocation effect is measured by the traded to nontraded output ratio. 
We have found Dutch Disease effects of migrant's remittances; a remittances elasticity of about 0.191 is found, suggesting that a doubling of per capita remittances raises real effective exchange rate by about 19 percent. On the other hand, a one percentage point increase in remittances to GDP leads to fall in traded to non-traded ratio by 0.016 . The magnitudes of both effects are substantial and economically significant. These findings imply a loss of international competitiveness, along with a decline in the traded manufacturing sectors in South Asian countries.

Foreign aid flows are largely statistically insignificant in both spending effect and resource movement effect regressions, suggesting that aid is not an important determinant of the real effective exchange rate, and has little impact on the composition of output. Moreover, in the case of tied aid, a substantial portion of aid goes back to the donor countries. This might be the reason for the statistical insignificance of aid flows in this study.

Over the period under consideration, the relative size of the service sector has been expanding, while the manufacturing sector has been contracting in South Asian countries, pointing to premature deindustrialization (Amirapu and Subramanian 2015). Flying geese patterns of industrialization, seen in East Asia, where relatively less industrialized countries follow a regional industrialized economy are therefore precluded. To widen the path of industryled growth in South Asia there should be structural transformation towards manufacturing sector and then service sector, but remittances can slow down this transformation or make it happen partially or miss it all together.

Although remittances may have a strong positive impact on poverty alleviation in this region by increasing household consumption, policy makers should also pay attention to its negative impact. Agriculture in South Asia still accounts for about 47 percent of total employment in 2013. Industrialization is necessary in this region to bring about structural transformation (Storm, 2015) and absorb surplus labour. 'Services-led' growth is either technologically less advanced, or when advanced, as in the IT sector, is too skill intensive to absorb surplus labour. Other services are typically non-traded, whose growth is constrained by domestic demand. Ultimately, manufacturing growth paves the way for service sector expansion. Therefore, without industrialization countries in this region may be mired in a quagmire of low level equilibrium trap.

\section{References}

Acosta, P. A., E. K.K. Lartey and F. S. Mandelman (2009) 'Remittances and the Dutch disease' Journal of International Economics 79: 102-116. 
Adams, JR. R. H. and J. Page (2005) 'Do International Migration and Remittances Reduce Poverty in Developing Countries? World Development 33(10): 1645-1669.

Afram, G. G.(2012) The Remittance Market in India Opportunities, Challenges, and Policy Options, World Bank, Washington D.C.

Amirapu, A. and A. Subramanian (2015) 'Manufacturing or Services? An Indian Illustration of a Development Dilemma' CGD Working Paper No. 409. Washington DC: Center for Global Development.

Amuedo-Dorantes and S. Pozo (2004) 'Workers' Remittances and the Real Exchange Rate: A Paradox of Gifts' World Development 32(8):1407-1417.

Balassa, B. (1964) 'The Purchasing Power Parity Doctrine: A Reappraisal' Journal of Political Economy 72:584-596.

Barajas, A., R. Chami, D. Hakura and P. Montiel (2011) 'Workers' Remittances and the Equilibrium Real Exchange Rate: Theory and Evidence' Economica 11(2):45-94.

Barajas, A., R. Chami, C. Fullenkamp, M. Gapen and P. Montiel(2009) 'Do Workers' Remittances Promote Economic Growth?’ IMF Working Paper No. 153, Washington D.C.: International Monetary Fund.

Bangladesh Bureau of Statistics (2014), 'Report on the Survey on Use of Remittance (SUR) 2013'. Dhaka: Bangladesh Bureau of Statistics.

Brakman, S. and C. V. Marrewijk (1998) The Economics of International Transfers, Cambridge: Cambridge University Press.

Bourdet, Y. and H. Falck (2007) 'Emigrants' Remittances and Dutch Disease in Cape Verde’ International Economic Journal 20(3): 267-284.

Burnside, C. and D. Dollar (2000) 'Aid, Policies, and Growth' The American Economic Review 90(4): 847- 868.

Cavoli, T. and R. S. Rajan (2013) 'South Asian Exchange Rates Regimes: Fixed, Flexible or Something In-between?’ South Asia Economic Journal 14(1):1-15.

Chami, R., D. Hakura and P. Montiel, 2009, "Remittances: An Automatic Stabilizer?," IMF Working Paper No. 09/91, Washington D.C.: International Monetary Fund.

Chowdhury, M. B. and F. Rabbi (2013) Workers' Remittances and Dutch Disease in Bangladesh, Journal of International Trade \& Economic Development: 23(4):455-475.

Corden, W. M. and J. P. Neary (1982) 'Booming Sector and DeIndustrialisation in a Small Open Economy' Economic Journal 92(368):825848.

Darvas, Z. (2012) 'Real Effective Exchange Rates for 178 Countries: A New Database’, Bruegel Working Paper No. 2012/06, Brussels: Brussels European and Global Economic Laboratory.

Dzansi, J. (2013) 'Do Remittance Inflows Promote Manufacturing Growth?' The Annals of Regional Science 51(1): 89-111.

Fielding, D. and F. Gibson (2012) 'Aid and Dutch Disease in Sub-Saharan Africa’ Journal of African Economies 0(0):1-21. 
Fischer, A. M. (2009) 'Putting Aid in Its Place: Insights from Early Structuralists on Aid and Balance of Payments and Lessons for Contemporary Aid Debates' Journal of International Development 21: 856-867.

Giuliano, P. and M. Ruiz-Arranz (2005) 'Remittances, Financial Development, and Growth' IMF Working Paper No. 234, Washington D.C.: International Monetary Fund.

Hoechle, D. (2007) 'Robust Standard Errors for Panel Regressions with CrossSectional Dependence' Stata Journal 7(3): 281-312.

International Organization for Migration (2009) 'Economic and Social Impacts of Remittances on Households: The Case of Pakistani Migrants Working in Saudi Arabia'. Geneva: International Organization for Migration.

International Organization for Migration (2010) 'The Bangladesh Household Remittance Survey 2009, Dhaka: International Organization for Migration.

Krugman, P. (1987) 'The Narrow Moving Band, the Dutch Disease, and the Competitive Consequences of Mrs. Thatcher' Journal of Development Economics 27: 41-55.

Lartey, E. K. K., F. S. Mandelman and P. A. Acosta (2012) 'Remittances, Exchange Rate Regimes and the Dutch Disease: A Panel Data Analysis' Review of International Economics 20(2): 377-395.

López, J. H., L. Molina and M. Bussolo (2008) 'Remittances, the Real Exchange Rate, and the Dutch Disease Phenomenon' in P. Fajnzylber and J. H. López (eds) Remittances and Development Lessons from Latin America ,pp. 217-252, World Bank, Washington D.C.

Leontief, W. (1936) 'A Note on the Pure Theory of Transfers' in Explorations in the Economics: Notes and Essays Contributed in Honor of F. W. Taussing, New York, McGraw-Hill, pp. 84-91.

Martins, P. M. G. (2013) 'Do Large Capital Inflows Hinder Competitiveness? The Dutch Disease in Ethiopia', Applied Economics 45(8).

Matsuyama, K (1992) 'Agricultural Productivity, Comparative Advantage and Economic Growth', Journal of Economic Theory, 58, 317-34.

Mughal, M. Y. (2013) 'Remittances as Development Strategy: Stepping Stones or Slippery Slope', Journal of International Development, 25, 583-595.

Mughal, M. Y. and F. Makhlouf (2013) 'Remittances, Dutch Disease, and Competitiveness: a Bayesian Analysis' Journal of economic development 38(2): 67-97.

Mundell, R. A. (1957) 'International Trade and Factor Mobility' The American Economic Review 47(3):321-335.

Naufal, G. and C. Vargas-Silva (2009) 'Changing Fertility Preferences One Migrant at a Time: The Impact of Remittances on the Fertility Rate' Discussion Paper No. 4066. IZA, Boon, Germany.

Nsor-Ambala, A. A. (2015) 'Foreign Transfers, Manufacturing Growth and the Dutch Disease Revisited, Discussion Paper No. 15 / 663, Department of Economics, University of Bristol. 
Nyoni, T. (1998) 'Foreign Aid and Economic Performance in Tanzania.' World Development 26(7):1235-1240.

Prati, A. and T. Tressel (2006) 'Aid Volatility and Dutch Disease. Is There a role for Macroeconomic Policies?’ IMF working Paper No. 06/145, Washington D.C.: International Monetary Fund.

Rahman, M. M., T. T. Yong and AKM A. Ullah (2014) 'Migrant Remittances in South Asia: An Introduction' in Rahman, M. M., T. T. Yong and AKM A. Ullah (eds), South Asia Social, Economic and Political Implications, pp. 1-30, Palgrave Macmillan.

Ratha, A. (2013) 'Remittances and the Dutch Disease: Evidence from Cointegration and Error-Correction Modeling' Economics Faculty Working Papers No. 26. St. Cloud State University.

Rajan, R. G. and A. Subramanian (2011) 'Aid, Dutch Disease, and Manufacturing Growth, Journal of Development Economics 94:106-118.

Rajan, R. G. and A. Subramanian (2006) 'What Undermines Aid's Impact on Growth?’ NBER working paper series No. 11657, Cambridge: National Bureau of Economic Research.

Roodman, D. (2009) 'How to Do xtabond2: An Introduction to Difference and System GMM in Stata' Stata Journal 9(1): 86-136.

Rodrik, D. (2015) 'Premature Deindustrialization' NBER working paper series No. 20935, Cambridge: National Bureau of Economic Research.

Sachs, J. (2009) 'Aid Ironies.' Huffington Post, May 24. Accessed 28 October $2015<$ http://www.huffingtonpost.com/jeffrey-sachs/aidironies_b_207181.html>.

Salter, W. E. G. (1959) 'Internal and External Balance: The Role of Price and Expenditure Effects' Economic Record 35(71): 226-238.

Samuelson, P. A. (1947) Foundations of Economic Analysis, Cambridge, Mass., Harvard University Press.

Samuelson, P. A. (1964) 'Theoretical Notes on Trade Problems' Review of Economics and Statistics 46:145-164.

Storm, S. (2015) 'Structural Change' Development and Change 46(4): 666-699.

Swan, T. W. (1960) 'Economic Control in A Dependent Economy' Economic Record 36(73):51-66.

World Bank (2014) World Development Indicators, Washington, D.C.: World Bank.

World Bank (2015) World Development Indicators, Washington, D.C.: World Bank.

World Bank (2015) Migration and Development Brief 24, Washington, D.C.: World Bank.

Yang, D. (2008) 'International Migration, Remittances and Household Investment: Evidence From Philippine Migrants' Exchange Rate Shocks' Economic Journal 118(528):591-630.

Yang, D. and H. Choi (2007) 'Are Remittances Insurance? Evidence from Rainfall Shocks in the Philippines' World Bank Economic Review 21(2):219_ 248. 


\section{Data Appendix}

Real Effective Exchange Rate (REER): This is an index which considers nominal exchange rate, consumer price indexes of domestic country and its trading partners. We have employed Darvas' (2012) dataset because the dataset contains REER for a longer time period.

$\operatorname{REER}_{t}=\frac{N E E R_{t} * C P I_{t}}{\operatorname{CPI}_{t}^{(\text {foreign })}}$

Where, $\mathrm{NEER}_{\mathrm{t}}=\prod_{i=1}^{N} S(i)_{t}^{w^{i}}$ is nominal effective exchange rate, geometrically weighted average of bilateral nominal exchange rate $\left[S(i)_{t}\right]$ between the domestic country and its trading partner $i$. And the bilateral nominal exchange rate is measured as the foreign currency price of one unit of domestic currency.

$C P I_{t}^{(f o r e i g n)}=\prod_{i=1}^{N} C P I(i)_{t}^{w^{i}}$, geometrical weighted average of consumer price index of the trading partners, $w^{i}$ is the weight of trading partner and $\mathrm{N}$ is the number of trading partners considered. $\sum_{i=1}^{N} w^{(i)}=1$.

Here $C P I_{t}$ is used as proxy for price of non-tradables, while $C P I_{t}^{(\text {foreign })}$ is used a proxy for price of tradables. Therefore, an increase in the index refers to appreciation, whereas a decrease refers to depreciation.

Traded to non-traded sector ratio (TNT): Following Lartey et al. (2012). We have taken sum of value added in the agriculture and manufacturing sector (as a share of GDP) as the proxy for the traded sector and value added in the service sector (as share of GDP) as the proxy for non-traded sector output. Data from World Bank 2015.

Remittances (\% of GDP): Remittances are defined as the sum of workers' remittances, compensation of employees, and migrants' transfers. Annual remittances data as of April 2015 (World Bank 2015) is used here. GDP data is taken from World Development Indicators, 2015 to express remittances as percent of GDP.

Per capita remittances (US \$): Population data is taken from World Development Indicators, 2015.

Foreign Aid (ODA+ Aid): Official Development Assistance (ODA) consists of concessional loans and grants provided by the members of Development Assistance Committee (DAC), by multinational institutions and, by nonDAC countries. While, official aid refers to the aid flows from official donors to DAC listed countries or territories. It is also measured in two scales -- per- 
cent of GDP and per capita. Foreign aid per capita is in current US dollar (World Bank 2014).

Foreign Direct Investment (FDI): Net foreign direct investment. FDI is the direct investment flows to domestic economy from foreign investors. FDI as percent of GDP is taken from World Development Indicators 2014.

Net Barter Terms of Trade (TOT): Index of relative prices of a country's export to imports. Rise in prices of export or fall in prices of imports indicates improvement in terms of trade. The index is calculated as the percentage ratio of the export unit value indexes to the import unit value indexes (Base year 2000=100)(World Bank 2014).

General government final consumption expenditure (GOVEX): Sum total of government current expenditures for purchases of goods and services. This also includes compensation of employees. This is measured in percent of GDP (World Bank 2014).

Per capita GDP (GDPPC): Per capita GDP is expressed in current US dollars (World Bank 2014).

Money and quasi money, M2, (percent of GDP): Sum total of currency outside banks, demand deposits other than those of the central government, savings, foreign currency deposits of resident sectors other than the central government, and time deposit (World Bank 2014).

Crop production index $(2004-2006=100)$ : It is the index of agricultural production of each year relative to the base year 2004-2006(World Bank 2015)

Primary school enrollment ratio: Percent of the population of official primary education age are enrolled in primary school (World Bank 2015). 